\title{
What Is 'Action' in Action Research: A Malaysian Exposure
}

\author{
T. Subahan Mohd. Meerah ${ }^{1} \&$ Kamisah Osman ${ }^{1}$ \\ ${ }^{1}$ Faculty of Education, Universiti Kebangsaan Malaysia, Selangor, Malaysia \\ Correspondence: Kamisah Osman, Faculty of Education, Universiti Kebangsaan Malaysia, 43600 UKM Bangi, \\ Selangor, Malaysia. Tel: 60-3-8921-3858. E-mail: kamisah@ukm.my
}

$\begin{array}{lc}\text { Received: August 16, } 2013 & \text { Accepted: October 14, } 2013 \quad \text { Online Published: November 28, } 2013 \\ \text { doi:10.5539/ass.v9n16p148 } & \text { URL: http://dx.doi.org/10.5539/ass.v9n16p148 }\end{array}$

\begin{abstract}
This paper discusses the concept of 'action' in action research. Novice teachers and teachers in school and higher education are encouraged to embark on researches related to their teaching in order to improve their teaching as well as students' learning. The inculcations of action research culture have been fostered at all educational levels (primary, secondary and tertiary) and are propagated as part of their practice to increase their professionalism as curriculum implementers in general. In this paper, a number of documents and papers related to action research at the National University of Malaysia were randomly analyzed by focusing on the 'actions' of the action researches that have been carried out. The paper also discusses the importance of providing training on understanding the purpose of 'action' in action research and the needs to share innovation particularly in teaching and learning with respect to the 'action' besides highlighting some of the training components and the 'action' itself.
\end{abstract}

Keywords: action research, teaching and learning, higher education

\section{Introduction}

The inculcation of action research among teachers at both levels, school and higher education has been timely. If changes and innovations in the education organization are desired, then the involvement of practitioners in research is important. In Malaysia, the roles of teachers as researchers began when the ministry decided to educate all teachers to conduct action research in the classroom, in stages through a professional development course, under the PIER (Program for Innovations, Excellence and Research) funded by the World Bank loan. The purpose of these programmes was to inculcate action research culture among the teachers. A number of teachers have participated in the training through a number of workshops, seminars and short courses. Some of the participants were selected as key personnel and then trained to conduct similar courses to other teachers through systematic in-house training. Thus far, many school teachers have the knowledge and skills to conduct action research. With the establishment of an academy (Higher Education Leadership Academy), a number of professional development training programs in the learning and teaching was conducted for Malaysian university lecturers since 2009, including four National Action Research Workshops; for university lecturers including the Public Higher Learning Institutions, Private Higher Learning Institutions and Malaysian Technical University Network.

In the last decade, Malaysian teachers have conducted practitioner research on various aspects of education specifically in learning and teaching in collaboration with the State Education Departments. In 1999, the Education and Research Planning Division of the Ministry of Education conducted a study involving 1564 teachers to find out the level of research activity in the schools and also evaluate the level of benefit gained from the research output on improving the teaching and organization quality of the school. The findings of the study showed that (i) the number of school teachers who have conducted research at the work place has increased (ii) a number of headmasters or principals has worked collaboratively with the teachers in conducting action research and (iii) the results of the research have benefited the teachers and schools administrators, thus improving the quality of teaching and school management. The results also showed there is a clear indication of positive effects on teachers who have carried out the action research. Although the percentage of teachers involving in the research is still relatively small and the number would be further increased, teachers now do not have to be too dependent on the results of external researchers and their own professional colleagues. The involvement of teachers in action research would thus improve the level of professionalism of teachers in the country. As summarized by Zuber-Skerritt (1996) the rationales and significance of conducting action research are that action 
research develop teachers who have (i) critical attitudes, (ii) reflective and practiced research on teaching, (iii) accountability (iv) self-evaluation and (v) high professional value. The concept of self-reflection as a way of improving one's own practice is similar to Schon's (1983) notion of reflective practice.

Malaysian Quality Assurance was set up nearly a decade ago to oversee and monitor higher institutions quality for accreditation purposes. This body has approved the implementation of outcome-based curriculum model in the development of higher education curriculums. Within the context of outcome based education, lectures need to vary their teaching approach. In this sense, lecturing method is no longer acceptable, Students need to be actively involved in the teaching and learning activities in much more stimulating learning environment. The National University of Malaysia is one of the first institutions in Malaysia that have advocated the use of the model accreditation. Not only that, the National University of Malaysia also promotes the idea of scholarship of teaching and learning whereby lecturers are encouraged to concentrate on research on teaching as well as in the research in the area of expertise. Through professional development courses, lecturers were introduced to educational courses on teaching and learning, which among all include research on their teaching.

Many studies have shown that to encourage and sustain action research among lecturers, they must be given recognition of carrying their work in the research. This research should be considered equivalent to the research in the particular field the lecturer professor. In a study on the level of motivations of school teachers in carrying action research, it was found that generally the teachers feel that they need some sort of recognition from the schools in general or departments in particular to encourage them to embark further in action research. What demotivates them more is when the head teachers or schools do not appreciate or provide them support and positive reinforcement for carrying out the research. Only a few teachers were intrinsically motivated and realized that doing action research was part of their reflective and accountable activity in their professions.

\section{The National University of Malaysia Action Research Practice}

In inspiring lecturers and teachers at the National University of Malaysia to conduct action research and hence stimulate their effort to improve their existing teaching practice, the university management motivates them to carry out action research in three ways:

1) By providing a small fund, a minimum of RM 10,000 to conduct action research ;

2) By recognizing the publication on the action research on their teaching and learning; and

3) By organizing a yearly teaching and learning congress for all action researchers to share their findings.

Over the past five years, we are currently witnessing an increased interest of lecturers carrying investigation of their own practice and the term practitioners' research has secured its place within university educational discourse. The university now regards it should be everybody one commitment to study one's own professional practice, even as a university researcher himself or herself, with a view of improve that practice for the benefit of university as a whole. The number of papers presented in the congress on teaching and learning also provide a good indication as well the numbers of participations in the poster exhibitions and best practices to foster the culture on the needs to share. Eventually the mission is towards improved employment opportunities among our graduates as a result of exposing and indulging themselves in a conducive teaching and learning environment.

\section{What 'Action' Means?}

It is clear that action research is a type of research. Some also regard it as a research methodology, while others accepted with some reservations. Nevertheless, the lecturers' research would give feedbacks on their experiences and research findings to other colleagues in their own field at the university or other universities, especially during the discipline-based forums, seminars and meetings. Not only that, when action research has been done, it is argued that the results can be used across other contexts. The action research can be classified according to one of the two purposes: i) To determine what is currently occurring [this could also entail inferential analysis] and ii) To test a hypothesis. With respect to the data analysis used, normally data garnered from action research study is descriptively analyzed as most of the researchers conducted action research in their classroom which involved all the students in the class.

What is crucially important is that in both types involve the desire to learn what the researchers need to know, to improve performance; it is only the focus that is different. When the focus is on the use of a new or modified 'idea' (a particular teaching and learning innovation) then the research becomes hypothesis type, a quasi-experimental research on investigating the adequacy of that 'idea', which Sagor (2005) labelled as the 'theory of action'. This is the most common form of action research whereas the 'descriptive action research' as it is called, when the researcher who want to do something about the problem but is not very clear enough with the issues in the context of the researcher own tutorial or classroom practice in order to be able to come up with a 
design of an effective strategy. More often, action research would help the researcher to understand the social situation being studied. Then, a study on the impact of the implementing of the 'action' would be the key towards understanding.

The most significant contribution of these studies will be of course on the adequacy of the actions (a theory of actions) that have helped to overcome the problem and as effective strategies for improvement in teaching and learning practice. Action research is thus an empowering strategy. Sagor (2005) also argued that researcher is expected to design the innovations, conduct the research, and consequently contribute to the body of professional knowledge. It is thus the professionals, who are in a position to identify the problems conduct the research that informs the practice; and integrate new insights into the existing routines or make adjustments in the operative theories of action. Being innovative in the development of a theory of action is not a choice, but it is essential for carrying out the research. Then the researcher systematically collects data to help the understanding what the impact is for both 'above' and 'below' the surface of the study. This is where the researcher would determine what is being accomplished and draw the relationship between the actions being taken and the results obtained. The cycle may be repeated until the researchers are satisfied on the impacts of the 'actions'. At the same time students' feedbacks is very important especially with regard to the teaching and learning innovations that have been tried upon them. Not only is that, their feedbacks vital in improving the innovation towards optimum effect on their learning.

Others may benefit from the research if they face similar situations. The purpose is to empower them in taking actions concerning their own 'actions' for the purpose of improving their future 'actions'. The actions could be adapting what is already known from previous action research, or new ideas, probably based on a theory or an innovation, which can be patented, if it is proved successful. Indirectly, it can be commercialized and at the same time increase the operative theory of actions in the development of each professional knowledge base. People who take the action are expected to design the innovations and to reiterate if it seems to work very well, the ideas or innovations can be commercialized.

On the notion of what is 'action', the proposals on the benefits of action research by proponents rarely explained what is meant by educational 'action'. Coulter (2002) contends that a clear conception of action is essential for educational action research and what counts as action is at least as important as what counts as research itself. However, Aristotle distinguished action as 'polesis' or making action from 'praxis' or 'doing action'. In this study, the author uses classification by Sagor (2005) which was suitable for the study and the analysis was done using the classification proposed.

\section{Action Research Cycle}

Analytical scrutiny of action research processes reveals that action research is a process in which participants examine their own educational practice systematically and carefully, using the techniques of research. Action research specifically refers to a disciplined inquiry done by a researcher with the intent that the research will inform and change his or her practices in the future (Glanz,. 1999). There are different types of action research depending upon the participants involved. However each action research will be applying the same basic action research cycle which comprise of i) identification of problem area; ii) collection and organization of data; iii) interpretation of data; iv) action based on data; and v) reflection. The research cycle is as Figure 1.

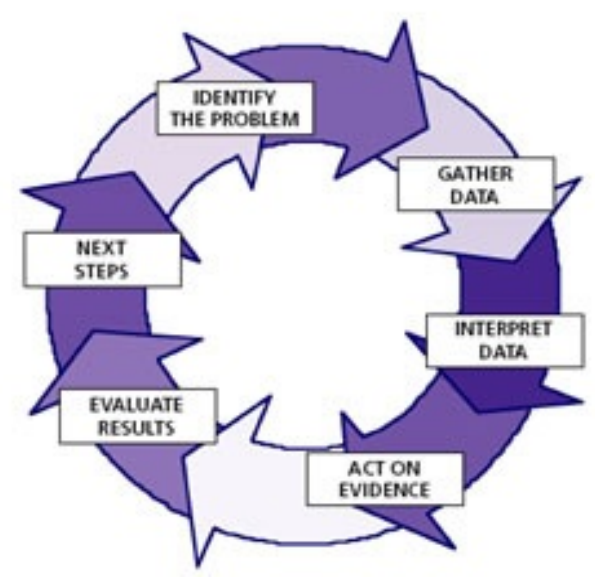

Figure 1. Action research cycle 
The first step in the action research cycle is identifying the problem. Researcher often has several questions they wish to investigate; however, it is important to limit the question to one that is meaningful and doable in the confines of their daily work. According to Ferrance (2000), careful planning at this first stage will limit false starts and frustrations. There are several criteria to consider before investing the time and effort in "researching" a problem. An important guideline in choosing a question is to ask if it is something over which the researcher has influence. Is it something of interest and worth the time and effort that will be spent? Data gathering step is an important step in deciding what action needs to be taken. Multiple sources of data are used to better understand the scope of happenings in the classroom, school or institution. In addition, the data need to be organized in a way that makes it useful to identify trends and themes. Based on the result of data interpretation, an action plan can be designed that will allow the researcher to make a change and to study the change. It is important that only one variable be altered in order to determine which action is responsible for the outcome. Finally it is essential to assess the effects of the intervention to determine if improvement has occurred. The cycle will be continuously going on until the desirable result is achieved (Carr \& Kemmiss, 1996).

\section{Results of a Random Analysis}

Most of papers presented or reports on action research conducted by numbers of lecturers from one faculty were carried out, to analyse the concern and actions taken using the classification proposed by Sagor (2005). All papers were meticulously read and analysed both on the concern and the action taken by the action researchers. The results of the findings showed that the concerns on these studies fall under five major categories as shown in the Table 1. Majority of the papers focussed on the measurement of the outcomes of the courses followed by effective implementation of outcome based curriculum. Other aspects that were also concerned by the lecturers were measurement and evaluation issues.

Table 1. Areas of concerned

\begin{tabular}{lll}
\hline 1 Quality of Student Learning & $\begin{array}{l}\text { Shahrom et al., 2011, Ishak et al., 2011, Siti Rozaimah et al., 2011, } \\
\text { Zulkifli et al., 2005 }\end{array}$ \\
$2 \begin{array}{l}\text { The Effects of Outcome-Based } \\
\text { Education Programmes on Students } \\
\text { Outcome }\end{array}$ & $\begin{array}{l}\text { Zulkifli et al., 2011, Baba et al., 2011, Mohd Jailani et al., 2005, } \\
\text { Noraini Hamzah et al., 2005, Abdul Khalim Abdul Rashid et al., }\end{array}$ \\
3 & $\begin{array}{l}\text { The Alternative Assessment or Scoring } \\
\text { Students Performance }\end{array}$ & $\begin{array}{l}\text { Haliza et al., 2011, Ramizi et al., 2005, Meor Zainal Abidin \& } \\
\text { Jamaliah, 2005, Nangkula et al., 2011, Izamarlina et al., 2011, } \\
\text { Hilmi Sanusi, 2011 }\end{array}$ \\
4 Organizing Laboratory Work & $\begin{array}{l}\text { Roszilah et al., 2011, Roszilah et al., 2005 } \\
\text { Norngainy et al., 2011, Azami Zaharim et al., 2005, Aini Hussain } \\
5 \text { et al., 2005, Amiruddin Ismail, 2005 }\end{array}$ \\
\hline
\end{tabular}

However, most of the studies are still in its infancy in the sense that most of the researches are descriptive type action research trying to understand the problem to inform the lecturers their future teaching directions. But there were studies which were more action oriented. For example in an action research study conducted by Subahan (2012), it described the development of a take-home electrical kit, for use by first year university students to strengthen their laboratory skills, knowledge on electricity and overcome misconceptions on electricity. The students would use and conduct the experiments with the kit at home and improve experimental skills and familiarize with the content in the prior knowledge of expected of them while continuing their studies at the university. As a result, the students would be quite ready for the university course on electricity or related subject and overcome some of the preparations and experience that have been missed in their prior secondary courses.

Currently, Malaysian schools are facing difficulties in encouraging student to take up science in upper secondary. Student found science to be difficult and not enjoyable. Wahid et al. (2011) were interested in the concern of school teachers who were confronted with many issues regarding teaching and learning of science. Realizing this, alternative methods of teaching science were being proposed. A collaborative action research was carried out among lecturers to work collaboratively with teachers on how environment awareness and knowledge can be taught to make students enjoy their learning and be informed about the environmental knowledge. LICHEN study was proposed by these groups of lecturers in measuring the quality of air by using simple apparatus which can be carried out outdoor. The study then reports the project work which was carried out collaboratively 
between university lecturers and teachers as well as students. A teaching module using LICHEN to measure quality of air in the environment was designed by the science lecturers. Working collaboratively with faculty's lecturers, a group of teachers from seven schools were selected to bring along 64 of their students to attend a project work and experience the use of LICHEN. The experiment involved measuring the quality of air, measuring and observing the LICHEN then they have to carry out the experiment repeatedly in three different areas to show the different air quality (for instance near the roadside, pond and open space). Each group would present and display the result. At the end of the experiment, the reaction from the teachers and students were very positive. Not only that they have gained the knowledge and valuable experimental competencies, but they also becoming more aware of the needs to sustain the environment.

Another similar study is a study conducted by Aznur Aisyah et al. (2012) who found that the existing books they used in teaching and learning of Japanese at the National University of Malaysia are not adequate for the learning of Japanese language skills. Thus, they designed and developed Japanese language learning materials, specifically for these purposes, namely Hiragana. Earlier, Sagor (2005) also demonstrates how she innovate the use of reflective practice to improve clinical practice in language. Reflective practice can be defined as the process of turning thoughtful practice into a potential learning situation. Since in clinical practice the students are required to plan before the commencement of procedure (reflection before action), during the procedure (reflection in action), and reviewing the procedure. In this study, undergraduate medical imaging students were prepared by simulated situations which were done by recording their performance and students were then given their own CD. They playback, comment and present to a panel of experts. Throughout these processes, feedback is provided immediately to correct the weakness. Whilst on clinical placement they complete weekly reflective diaries, which will generally relate to 'reflection on action'. The aim of this type of reflection is for the practitioners, by reviewing an incident and to use the result of this analysis as a means to improve future practice. Undoubtedly, reflective practice is a tool that is believed to result in both improvement in patient care and accelerate professional development. It is therefore be argued that the emergence of reflective practice is part of a change process that acknowledges the needs for students to act and to think professionally as an integral part of learning throughout their course of study.

\section{Conclusion}

It could be concluded that lectures at the National University of Malaysia are currently active in immersing themselves in action research culture. Such scenario paints a rich picture of the commitment shown by the lectures as well as the university's top management in improving teaching and learning process while at the same time ensuring the attainment of course and programme learning outcomes. Not only is that, on part of the lectures, the long term effect cultivation of reflective practice which geared them towards continuously improving their own teaching. As for the students, such learning experience would shape them as graduates equipped with necessary skills that are required by their profession and hence increase their employability.

\section{References}

Abdullah, S. R. S., Anuar, N., \& Mohamad, A. B. (2011). Pengukuran dan hasil pembelajaran program dalam pelaksanaan kursus projek ilmiah di Jabatan Kejuruteraan Kimia dan Proses. Kertas Kerja Seminar Pendidikan Kejuruteraan \& Alam Bina, Kongres Pengajaran dan Pembelajaran UKM 2011. pp. 117-124.

Aisyah, A., Hieda, N., \& Nezu, M. (2012). Pengenalan Tulisan Bahasa Jepun- Katakana. Bangi: Penerbit Universiti Kebangsaan Malaysia, UKM.

Arshad, I., Razali, S. F. M., \& Mohamad, Z. S. (2011). Pengukuran hail pembelajaran program melalui peperiksaan akhir bagi program kejuruteraan awam dan struktur. Kertas Kerja Seminar Pendidikan Kejuruteraan \& Alam Bina, Kongres Pengajaran dan Pembelajaran UKM 2011. pp. 81-86.

Carr, W., \& Kemmis, S. (1996). Becoming critical: Education, knowledge and action research. Lewes. Falmer Press.

Coulter, D. (2002). What Counts As Action in Educational Action Research. Educational Action Research, 10, 189-206. http://dx.doi.org/10.1080/09650790200200181

Deros, B. M., Mohamed, A., Mohamed, N., \& Ihsan, A. K. A. M. (2011). A study of alumni feedback on outcome based education: Master of Engineering in manufacturing systems. Kertas Kerja Seminar Pendidikan Kejuruteraan \& Alam Bina, Kongres Pengajaran dan Pembelajaran UKM 2011. pp. 281-286.

Ferrance, E. (2000). Themes in Education. Action Research. Northeast and Islands Regional Educational.

Glanz, J. (1998). Action research: An educational leader's guide to school improvement. Norwood, 


\section{MAChristopher-Gordon.}

Ismail, A., Hussain, A., Zaharim, A., Rashid, A. K. A., Anuar, N., Nopiah, Z. M., \& Nor, M. J. M. (2005). Menjana kecemerlangan di kalangan pelajar kejuruteraan UKM. Pascasidang Seminar Pengajaran dan Pembelajaran Berkesan, Fakulti Kejuruteraan, UKM. pp. 32-40.

Malaysian Quality Assurance. (2012). Quality assuring higher education in Malaysia. Retrieved from http://www.mqa.gov.my/portal2012/contrast/en/news_20120419.cfm

Nopiah, Z. M., Baharin, M. N., Razali, N., \& Tawil, N. M. (2011). An outcome-based approach analysis of a course in mathematical engineering. Kertas Kerja Seminar Pendidikan Kejuruteraan \& Alam Bina, Kongres Pengajaran dan Pembelajaran UKM 2011. pp. 174-180.

Nopiah, Z. M., Zaharim, A., Ismail, A. H., Ihsan, A. K. A. M., \& Nor, M. J. M. (2005). Learning styles of the Malay-Muslim Engineering Students Towards Mathematics at The Universiti Kebangsaan Malaysia. Pascasidang Seminar Pengajaran dan Pembelajaran Berkesan, Fakulti Kejuruteraan, UKM. pp. 41-45.

Othman, H., Asshari, I., Bahaludin, H., Ismail, N. A., \& Nopiah, Z. M. (2011). Evaluating the reliability and quality of final exam questions using rasch measurement model: A case study of engineering mathematics courses. Kertas Kerja Seminar Pendidikan Kejuruteraan \& Alam Bina, Kongres Pengajaran dan Pembelajaran UKM 2011. pp. 163-174.

Sagor, W. (2005). The Action Research Guidebook. London, Corwin Press.

Sanusi, H. (2011). Measurement of students creativity using black box' experiment. Kertas Kerja Seminar Pendidikan Kejuruteraan \& Alam Bina, Kongres Pengajaran dan Pembelajaran UKM 2011. pp. 111-116.

Schon, D. (1983). The reflective practioners: How professionals thinks in action. Basic Books: New York

Subahan, T. (2012). Developing laboratory skills through take home experiments for first year science and engineering students. The Third Regional Conference On Engineering Education And Research In Higher Education.

Tawil, N. M., Ismail, N. A., Shhari, I., Osman, H., Nopiah, Z. M., \& Zaharim, A. (2011). E-learning versus traditional in teaching mathematics and statistics courses for engineering students in UKM. Kertas Kerja Seminar Pendidikan Kejuruteraan \& Alam Bina, Kongres Pengajaran dan Pembelajaran UKM 2011. pp. 321-326.

Utaberta, N., Hassanpour, B., Ibrahim, N. L. N., \& Zaharim, A. (2011). Reconstructing framework for criteria-based assessment in 2nd years architecture design studio UKM. Kertas Kerja Seminar Pendidikan Kejuruteraan \& Alam Bina, Kongres Pengajaran dan Pembelajaran UKM 2011. pp. 148-155.

Wahid, S., Zuriati, Z., Rusli, D., Subahan, T., Sharina, S. I., \& Halim, L. (2011). Lichens in the environment as a laboratory for environmental and science education. Procedia Social and Behavioral Sciences, 59, 627-634.

Zaharim, A., Ahmad, I., \& Abdullah, F. (2005). A new approach teaching statistics course for the engineering faculty: A student Prespective. Pascasidang Seminar Pengajaran dan Pembelajaran Berkesan, Fakulti Kejuruteraan, UKM. pp. 93-99.

Zain, S. M., Badaruzzaman, W. H. W., Rahmat, R. A. O. K., Jaafar, O., Basri, N. E. A., \& Basri, H. (2011). Pengukuran hasil pembelajaran bagi komponen alam sekitar dan pembangunan lestari dalam bidang kejuruteraan. Kertas Kerja Seminar Pendidikan Kejuruteraan \& Alam Bina, Kongres Pengajaran dan Pembelajaran UKM 2011. pp. 69-80.

Zuber-Skerritt, O. (1996). New directions in action research. London: Falmer Press.

\section{Copyrights}

Copyright for this article is retained by the author(s), with first publication rights granted to the journal.

This is an open-access article distributed under the terms and conditions of the Creative Commons Attribution license (http://creativecommons.org/licenses/by/3.0/). 